\title{
КОМПАРАТИВНИЙ АНАЛІЗ МЕТОДІВ ПРОТИДІЇ ЛЕГАЛІЗАЦІЇ (ВІДМИВАННЮ) ДОХОДІВ, ОДЕРЖАНИХ ЗЛОЧИННИМ ШЛЯХОМ
}

\author{
Коваль Яна Сергї̈вна, \\ кандидат наук з державного управління, \\ дочент кафедри управління фінансово-економічною безпекою, \\ ВНЗ «Університет економіки та права «КРОК», \\ ORCID: https://orcid.org/0000-0001-6578-2996
}

Анотація. У розділі досліджено основні принципи та методи боротьби з легалізацією (відмиванням) доходів, одержаних злочинним шляхом. Така боротьба $є$ важливим складником формування вищого рівня визначеності економічних відносин усередині країни та в міжнародних стосунках. Ідентифіковано функції міжнародних організацій, які координують роботу в сфері запобігання та протидії легалізації (відмиванню) доходів. Розглянуто основні схеми легалізації (відмивання) доходів, одержаних злочинним шляхом. Визначено пріоритети застосування досвіду інших країн у реформуванні української системи фінансового моніторингу.

Ключові слова: доходи, одержані злочинним шляхом, фінансовий моніторинг, механізми протидії легалізації доходів, бенефіціар, національна оцінка ризиків.

Сучасні зміни у національних системах фінансового моніторингу в різних країнах світу визначаються необхідністю легалізації доходів, одержаних злочинним шляхом, та фактами фінансування тероризму. Як показує досвід різних країн, поряд 3 державними органами, що здійснюють збір податків та платежів, питаннями фінансової безпеки опікуються й спеціалізовані фінансові інституції. Йдеться про проблему легалізації (відмивання) доходів, одержаних злочинним шляхом, що набула ознак міжнародної. Різні схеми «відмивання» грошей стають транснаціональними. Вони пов'язані 3 організованою злочинністю (фінансовими аферистами, наркобізнесом, фінансуванням тероризму тощо). Аналізована нами проблема пов'язана з загрозами фінансовоекономічній безпеці та економічній стабільності. Дослідження досвіду протидії легалізації (відмиванню) доходів, одержаних злочинним шляхом, $\epsilon$ актуальним, з огляду на можливість його застосування в Україні.

Метою дослідження є компаративний аналіз методів протидії легалізації (відмивання) доходів, одержаних злочинним шляхом, для визначення можливостей застосування їх використання в українській економіці. 
У сучасному світі спостерігається удосконалення способів скоєння злочинів та методів приховування їх негативних наслідків. Розвиток новітніх технологій призвів до правопорушень 3 використанням сучасних комунікацій. До злочинних дій, скоєння яких відбувається з використанням технічних результатів наукового прогресу, належить і легалізація доходів, отриманих незаконним шляхом.

Для попередження ухилення від сплати податків та інших фінансових злочинів створюються підрозділи фінансової розвідки. Вони виконують аналітичні функції збору й обробки інформації. Відмінності між підрозділами фінансової розвідки визначаються специфікою їх діяльності, функціональними можливостями тощо. Проте всі згадані підрозділи мають бути орієнтовані на координацію діяльності.

У деяких країнах підрозділи фінансової розвідки $\epsilon$ адміністративними органами, в інших - діють в якості поліцейських та юридичних органів. Досвід країн з розвиненими фінансовими розвідками свідчить про те, що ефективність їх роботи визначається лише наявністю визначеної правової бази й ефективністю системи збору, обробки, передачі та надання фінансової інформації, ідентифікації ініціаторів фінансових операцій [1].

Відмивання «брудних» грошей є складним економіко-правовим явищем, яке не має кордонів. Термін «відмивання грошей» з'явився в науковому обігу порівняно нещодавно. Проте світова спільнота уже встигла продемонструвати серйозність своїх намірів у боротьбі з цим злом.

Шляхи передачі інформації в різних країнах суттєво впливають на ефективність фінансового моніторингу загалом. Лише прямі канали передачі інформації від підрозділів фінансової розвідки до фінансових інститутів та регуляторів сприяють ефективності фінансового моніторингу. У випадку передачі інформації від фінансових посередників до державних регуляторів у сфері фінансів, а потім до підрозділів фінансової розвідки ефективність національної системи фінансового моніторингу значно зменшується.

Глобалізаційні та інтеграційні процеси, стрімкий розвиток інформаційних технологій призвели до того, що проблема легалізації злочинних доходів вийшла на міжнародний рівень.

На сьогодні легалізації доходів властиве постійне ускладнення схем, прискорення проведення незаконних операцій, а також потреба у використанні транзитних банківських рахунків. Це призводить як до серйозних втрат економічних ресурсів, так і репутації банків. Загальні масштаби такої загрози для банківського сектору можна охарактеризувати кількістю вжитих до них санкцій. Саме санкції вказують на їх причетність до легалізації доходів, отриманих незаконним шляхом, та на невиконання вимог законодавства в цій сфері [2]. 
Механізми протидії легалізації доходів незаконного походження у фінансових організаціях повинні безперервно вдосконалюватися. Це дозволить якісно аналізувати інформацію, яка надходить, своєчасно виявляючи в ній відомості про операції, пов'язані з легалізацією злочинних доходів, забезпечувати фінансову безпеку банку, сприяти раціональному використанню його ресурсів та досягненню стратегічних цілей.

Широкомасштабне «відмивання» нелегальних доходів загальносвітова проблема, яка вимагає рішення з боку всіх держав світу. Для початку кожна держава повинна самостійно визнати це діяння злочинним і внести відповідні зміни й доповнення у внутрішне законодавство. Саме від цього буде залежати успіх боротьби з цим серйозним і небезпечним видом злочинів в усьому світі.

Ефективне міжнародне співробітництво у сфері боротьби 3 тероризмом 3 урахуванням цих негативних процесів неможливе без скоординованої роботи міжнародної спільноти. Йдеться про характер сучасного тероризму. Він вимагає глобального реагування на такі виклики на засадах міжнародної співпраці й кооперації [3].

Аналіз становлення правового регулювання співробітництва держав-членів Свропейського Союзу з протидії легалізації доходів, отриманих злочинним шляхом, $є$ надзвичайно актуальним. Це дає можливість прослідкувати еволюцію такої співпраці та шляхи вдосконалення форм і механізмів колективної діяльності держав у цій сфері. Такі механізми одночасно можуть стати взірцем кращих практик, спрямованих на підвищення ефективності як національних заходів із боротьби з відмиванням «брудних» грошей, так і тих, які можуть бути застосовані в інших регіональних утвореннях.

Як правило, міжнародне співробітництво у сфері боротьби 3 тероризмом здійснюється шляхом:

- встановлення на міжнародному рівні єдиних підходів щодо притягнення до кримінальної відповідальності за тероризм та його прояви;

- розробки та укладання міжнародних договорів у сфері боротьби 3 тероризмом, прийняття інших міжнародних документів як правової основи регулювання діяльності держав, міжнародних організацій у цій сфері [4].

Практично ця діяльність може мати характер співробітництва у сфері вироблення єдиної державної політики щодо запобігання тероризму, оперативного обміну інформацією між органами кримінальної юстиції, кримінального переслідування терористів і притягнення їх до відповідальності. 
Міжнародне співробітництво у боротьбі з сучасним тероризмом грунтується на таких принципах:

- принцип осуду тероризму, незалежно від цілей терористів, що закріплено практично в усіх міжнародних конвенціях про боротьбу 3 тероризмом;

- відмова від будь-яких форм (фінансова, військово-технічна та ін.) сприяння терористам;

- співробітництво на світовому рівні в боротьбі з фінансовими й технологічними можливостями сучасного тероризму;

- захист світових культур і релігій від екстремістського впливу тероризму;

- дотримання норм міжнародного права [5].

«Відмивання» незаконно отриманих доходів завжди відбувається не в країні, де знаходиться їх джерело походження, а за кордоном. Саме цей факт зумовлює розвиток міжнародного співробітництва у боротьбі з «відмиванням» грошей. Він базується на таких принципах:

- прийняття відповідних міжнародних і національних нормативноправових актів;

- укладання угод про правову допомогу в боротьбі 3 «відмиванням» грошей;

- розробка міжнародних програм протидії «відмиванню» грошей;

- прийняття відповідних документів міжнародними економічними, фінансовими, політичними і правоохоронними організаціями, економічними союзами;

- створення спеціальних міжнародних та національних правових і силових структур;

- упровадження певних правил з обміну іноземної валюти;

- посилений нагляд за офшорними секторами економіки;

-удосконалення електронного архіву міжнародних грошових переказів;

- створення програм з навчання фахівців банківської сфери;

- встановлення міжнародних стандартів бухгалтерського обліку та механізмів контролю за їх дотриманням;

- публікація «чорних» списків країн;

-блокування банківських активів при виявленні підозрілих операцій;

-випуск спеціальних міжнародних видань 3 проблематики «відмивання» грошей [6].

Існує ціла система протидії легалізації грошей, аспекти якої зображені на рис. 1. 


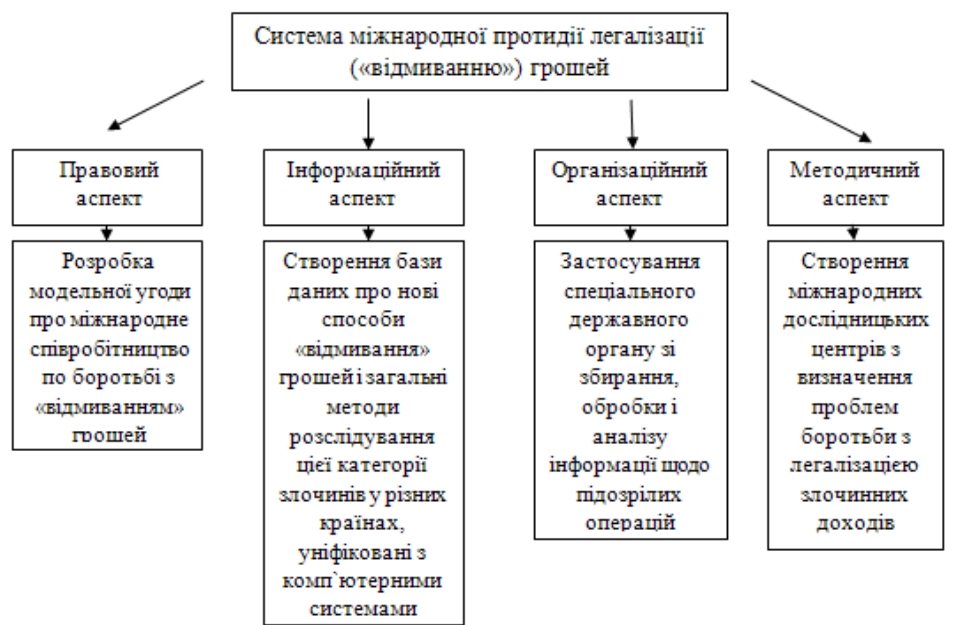

Рис. 1. Система міжнародної протидії легалізації («відмиванню») доходів, одержаних злочинним шляхом

Джерело: сформовано автором на основі [7-12].

Доцільно розглянути більш детально зарубіжний досвід.

Сполучені Штати Америки, як країна 3 провідною економікою світу, одні з перших почали вживати заходів щодо легалізації злочинних доходів. Керівні органи країни створили систему протидії різним схемам 3 легалізації доходів, одержаних злочинним шляхом. Важливим елементом цієї системи стало формування законодавчої бази щодо регулювання діяльності фінансових інститутів.

Більшість експертів початок боротьби з легалізацією доходів у США датують 1970 р., тобто прийняттям Закону «Про банківську таємницю». Цей Закон визначав зобов'язання фінансових установ зберігати облікову документацію про проведені операції. Таким чином, були закладені передумови розвитку системи фінансового моніторингу в США. А вже у 1986 р. дії, спрямовані на «відмивання» грошей, були юридично класифіковані як злочин, відповідно до прийнятого Закону «Про контроль над відмиванням грошей».

Основним законом, який регулює особливості здійснення фінансового моніторингу в США, $є$ PATRIOT Act 2001. Його основною метою $є$ обмеження доступу до фінансової системи США шляхом уведення більш суворих вимог стосовно іноземних фінансових інститутів, що відкривають кореспондентські рахунки в американських банках. У зв'язку з цим усі американські фінансові інститути повинні розробляти та вдосконалювати програми для виявлення операцій 3 відмивання грошей [13]. 
У разі порушення законодавства у сфері протидії легалізації доходів, отриманих злочинним шляхом, та фінансуванню тероризму адміністративну та/чи кримінальну відповідальність у США несуть не тільки злочинці, а й суб’ єкти фінансового моніторингу. Зокрема, американський банк, що обслуговує рахунок нерезидента, зобов'язаний припинити всі відносини з іноземним контрагентом не пізніше ніж через 10 робочих днів після одержання письмового повідомлення від Міністра фінансів чи Генерального Прокурора про те, що іноземний банк відмовився відповісти на запит, і почати процесуальні дії в суді США зі встановленню правомочності цього запиту. Відмова завершити кореспондентські відносини в рамках вищевказаних умов погрожує санкцією у відношенні до американського фінансового інституту у вигляді штрафів у розмірі до 10 тис. дол. за кожний день, доти, поки ці відносини не будуть припинені.

У банківській сфері США протидією легалізації злочинних доходів займаються такі контрольні органи:

- Апарат ревізора з грошового обігу;

- Федеральна корпорація зі страхування вкладів;

- Правління Федеральної резервної системи;

- Управління з контролю за дотриманням законності;

- Національна адміністрація кредитної спілки [14].

Зазначені відомства розробили спеціальні методики для розпізнавання можливих порушень і злочинної діяльності в банківській сфері. Під час проведення перевірки банківських структур названі вище органи контролю можуть зосередити увагу на фактах потенційного шахрайства, внутрішніх зловживань та інших злочинних діях, у тому числі пов'язаних 3 відмиванням грошей. Для перевірки дотримання Закону «Про банківську таємницю» або розслідування можливих порушень будь-яких інших нормативно-правових актів ці відомства можуть здійснювати банківські ревізії. Наприклад, Федеральна корпорація зі страхування вкладів створила свій відділ з економічних злочинів, до якого ввійшли спеціально підготовлені інспектори 3 вивчення можливої злочинної діяльності.

Таким чином, на сьогодні у США створена одна 3 найбільш ефективних систем протидії легалізації доходів та фінансування тероризму. Це зумовлено, на наш погляд, насамперед тим, що США, маючи одну з провідних економік світу, володіють широкою мережею як кредитних організацій міжнародного рівня, так і кредитних організацій, що популярні більше на внутрішньому ринку США.

У Франції організацію фінансового моніторингу регулюють два основних нормативно-правових акти: Закон «Про участь фінансових інститутів у боротьбі з відмиванням грошей від незаконного обігу наркотиків» та Валютно-фінансовий кодекс. 
Спеціальним підрозділом фінансової розвідки у Франції є TRACFIN. Він підпорядковується Міністерству фінансів, а його діяльність $€$ засекреченою [15].

Особливістю системи фінансового моніторингу у Франції є те, що вона не має законодавчо закріплених вимог щодо надання інформації про фінансові операцій в залежності від їх суми. Критеріями дослідження операцій на сумнівність $є$ вмотивована підозра щодо фінансових операцій, які мають ознаки легалізації доходів. Ідеться про кошти, які можуть стосуватися незаконної торгівлі наркотиками, організованої злочинності, вчинення шахрайських дій, корупції. Особливої уваги від суб'єктів первинного фінансового моніторингу потребують фінансові операції. Йдеться про суми, які перевищують 150 тис. євро та характеризуються складністю проведення або відсутністю економічного сенсу.

Надавати інформацію до TRACFIN про нетипові фінансові операції зобов'язані фінансові інститути: банки та кредитні установи, платіжні організації, страховики, інвестиційні компанії, ломбарди. Також це здійснюють фізичні й юридичні особи, які професійно займаються фінансовою та пов'язаною з нею діяльністю: посередники з нерухомості, власники казино, клуби і компанії, що організовують азартні ігри, лотереї, спортивні ігри, суб'єкти, які здійснюють торгівлю дорогоцінностями, антикваріатом, творами мистецтва, бухгалтери, аудитори, нотаріуси, судові виконавці, керівники та законні представники, компанії з продажу майна на публічних торгах й інші [16]. Фінансовий моніторинг у Німеччині здійснює підрозділ фінансової розвідки (Zentralstelle für Verdachtsanzeigen), який входить до складу поліції.

Фінансово-кредитні установи у Німеччині зобов'язані здійснювати ідентифікацію клієнта й у випадку перевищення суми фінансової операції 15 тис. євро (або у випадку встановлення довгострокових відносин), і у випадку, якщо фінансова операція викликає мотивовану підозру щодо відмивання кримінальних доходів. Окрім ініціатора фінансової операції, фінансові установи Німеччини зобов'язані встановлювати особу бенефіціара підозрілої операції.

Цікавим є той факт, що Центральний банк у Німеччині (Бундесбанк) не має повноважень регулювання та нагляду в сфері протидії легалізації доходів, отриманих злочинним шляхом та фінансуванню тероризму. Сам банк належить до фінансових установ, які здійснюють комерційні фінансові операції. Таким чином, Бундесбанк, як й інші фінансовокредитні установи Німеччини, зобов'язаний звітувати про підозрілі фінансові операції [17].

Нагляд за діяльністю фінансових установ у Німеччині здійснює Федеральне відомство нагляду за діяльністю фінансових установ (BaFin). Окрема Група нагляду за здійсненням фінансовими установами 
заходів щодо запобігання легалізації кримінальних доходів у складі BaFin включає 4 сектори: політичних рішень і міжнародного співробітництва; перевірок банківських установ; перевірок страховиків та установ, що здійснюють.

Особливу увагу протидії відмиванню злочинних доходів та фінансуванню тероризму з метою забезпечення фінансової безпеки приділяють у Канаді. За даними підрозділу фінансової розвідки Канади Financial Transaction and Report Analysis Center (FINTRAC), щорічний обсяг злочинних доходів у світі коливається в межах 590 млрд - 1,5 трлн дол. США. Тому повноваження FINTRAC щодо протидії легалізації незаконних доходів розповсюджуються на всі види фінансових злочинів, у тому числі торгівлю наркотиками, фінансові махінації, ухиляння від сплати податків, корупцію та інші [18].

FINTRAC, який підпорядковується Міністерству фінансів Канади, було створено у 2000 р. відповідно до Закону Канади «Про протидію відмиванню незаконних коштів та фінансуванню тероризму». У 2002 році FINTRAC став членом Егмонтської групи підрозділів фінансової розвідки. Сьогодні FINTRAC співпрацює з більш як 100 підрозділами фінансових розвідок різних країн щодо обміну інформацією та досвідом у сфері протидії легалізації доходів, отриманих злочинним шляхом та фінансуванню тероризму.

Метою діяльності FINTRAC є сприяння громадській безпеці Канади й захист цілісності фінансової системи країни шляхом виявлення та запобігання легалізації доходів і фінансування тероризму.

Як зазначає дослідник Іваницька О. М., специфічною ознакою діяльності фінансового моніторингу в Канаді є багатоджерельність отримання інформації. Основними джерелами інформації, що використовують у процесі фінансового моніторингу FINTRAC, є: добровільно надана інформація (59\%), повідомлення про підозрілі операції (13\%), профільні доповіді (5\%), інформація з відкритих джерел (3\%) та запити підрозділів фінансової розвідки (20\%) [19].

Тобто зі всієї кількості отриманої інформації щодо відмивання злочинних доходів лише $13 \%$ становить інформація, яку зобов'язані подавати фінансові установи та інші суб'єкти первинного фінансового моніторингу. Це свідчить про високий рівень організації фінансового моніторингу і фінансової системи загалом та високий рівень свідомості суб'єктів, які ініціюють чи здійснюють фінансові операції.

У разі порушення законодавства у сфері протидії легалізації злочинних доходів і фінансуванню тероризму в Канаді застосовують як штрафні санкції до 2 млн дол. США, так і відповідальність у вигляді позбавлення волі до 5 років.

Система фінансового моніторингу в Канаді постійно перебуває в стадії динамічного розвитку. Останні напрями іiї удосконалення 
спрямовані на розробку єдиної національної системи оцінки ризиків легалізації злочинних доходів із упровадженням нормативного процесу оцінки ризиків для окремих секторів фінансової системи та окремих продуктів сфери фінансових послуг.

У Польщі основний Закон «Про протидію відмиванню грошей та фінансуванню тероризму» в сфері протидії легалізації злочинних доходів було прийнято у 2000 р. Згідно з чинним законодавством Польщі обов'язковому фінансовому моніторингу підлягають фінансові операції на суму, що в еквіваленті становить 15 тис. євро та більше.

Центральним елементом системи державного фінансового моніторингу в Польщі $є$ Генеральний інспектор фінансової інформації (Generalny Inspektor Informacji Finansowej - GIIF), підпорядкований Міністерству фінансів. Мета GIIF - отримання, збирання, обробка та аналіз інформації для запобігання легалізації активів незаконного або невизначеного походження і запобігання фінансуванню тероризму. Вчинення злочину щодо легалізації будь-яких активів, отриманих у незаконний спосіб, у Польщі карається позбавленням волі від 6 місяців до 10 років з можливою конфіскацією майна [20].

У Білорусі на законодавчому рівні та в політичній сфері відсутня єдина стратегія боротьби з легалізацією доходів, отриманих злочинним шляхом, а фінансовий моніторинг розглядають як частину інших державних програм. Єдиний координаційний орган - підрозділ фінансової розвідки - відсутній. Частину його обов'язків виконує Департамент фінансового моніторингу Комітету державного контролю Республіки Білорусь. Більшість (98\%) повідомлень про підозрілі фінансові операції передаються в електронній формі від банківських установ, а решта - у паперовій формі. Їх потім вручну вносять до системи. Як визначено у звіті Комітету державного контролю Республіки Білорусь, Департамент фінансової розвідки, інші правоохоронні органи та прокуратура не надають регулярно державному фінансову моніторингу зворотній зв'язок про використання переданих матеріалів [21].

В Італії фінансовий моніторинг покладено на Ufficio Italiano Combi UIC (SAR), що підпорядковується Національному банку Італії. Першою та другою частиною положення про фінансові операції i звітністю Національного Банку Італії визначено правила проведення фінансового моніторингу фінансовими установами на всій території Італії. Чинне законодавство країни передбачає ведення банками й іншими фінансовими посередниками детальної документації щодо всіх валютних операцій клієнтів-резидентів. У 2014 р. до UIC (SAR) надійшло 49 тис. доповідей про підозрілі фінансові операції.

У Великій Британії питаннями фінансового моніторингу опікується підрозділ фінансової розвідки - Служба внутрішніх доходів NCIS / ECU. Вона підпорядковується Міністерству фінансів Великої Британії 
та взаємодіє з Національною службою кримінальної розвідки, Митноакцизною службою, Бюро для боротьби 3 шахрайством, Службою національних розслідувань. NCIS / ECU Великої Британії займається питаннями протидії легалізації доходів, фінансування тероризму, злочинів у сфері грального бізнесу, шахрайств. Проте англійське законодавство забороняє передачу інформації про податкові правопорушення іншим державам. 32005 р. у національній системі фінансового моніторингу Великої Британії намітилися тенденції до посилення координації діяльності всіх учасників протидії легалізації доходів [22].

У зв'язку з тим, що процес легалізації (відмивання) доходів, одержаних злочинним шляхом, реалізується переважно 3 використанням міжнародних злочинних зв'язків, були створені спеціальні міжнародні організації, які здійснюють координацію роботи у сфері запобігання та протидії легалізації злочинних доходів. Такими організаціями на сьогоднішній день $є$ :

1. Група з розробки фінансових заходів боротьби з відмиванням грошей (FATF) - міждержавна організація, створена у липні 1989 р. на нараді керівників країн Великої Сімки у Парижі «для оцінки поточних результатів співпраці у сфері запобігання використання банківської системи і фінансових установ для відмивання доходів, одержаних злочинним шляхом, та розгляду можливості прийняття додаткових превентивних заходів у даній сфері».

2. Егмонтська група (Група підрозділів фінансової розвідки «Егмонт») - неформальне об'єднання національних відомств, що виконують функції фінансової розвідки, створене у червні 1995 р. у Брюсселі представниками 24 країн та низки міжнародних органів, включаючи FATF, Інтерпол, Європейську комісію, Всесвітню митну організацію та ін. Членство в ЕГ є однією з вимог рекомендацій FATF.

3. MONEYVAL - спеціальний комітет експертів PС 3 питань взаємної оцінки заходів протидії відмиванню коштів та фінансуванню тероризму, створений у вересні 1997 р. рішенням Комітету Міністрів Р€ для здійснення загального й незалежного аналізу боротьби 3 легалізацією злочинних коштів у країнах-членах Р€ (і країнах-кандидатах на вступ до РЕ), які не є членами FATF.

4. Євразійська група 3 протидії легалізації злочинних доходів і фінансуванню тероризму (САГ) - об'єднання, створене у жовтні 2004 p. шляхом підписання Декларації офіційними представниками урядів Республік Білорусь, Казахстан, Киргизстан, Таджикистан, Китаю, Російської Федерації за типом FATF.

5. Базельський комітет (Комітет регулювання та нагляду за банківською діяльністю) - спеціальний орган, створений у 1974 р. під егідою Банку міжнародних розрахунків на основі укладеної 10-ма розвиненими країнами угоди (так званий Базельський конкордат). 
6. Вольфсберзька група - міжбанківське об'єднання, створене у 2000 p. 11-ма найбільшими банками світу.

7. ООН - міжнародна організація, яка об'єднує 192 країни світу. Статут ООН був підписаний 26 червня 1945 р. на конференції в СанФранциско (США) і вступив у силу 24 жовтня 1945 р.

8. Міжнародний валютний фонд - універсальна міжнародна фінансова організація, заснована відповідно до угод, прийнятих на Міжнародній валютно-фінансовій конференції ООН у липні 1944 р. у США, та набула чинності з грудня 1945 р.

9. Світовий банк - одна 3 найбільших у світі організацій, що надають допомогу з метою розвитку, заснована у $1944 \mathrm{p}$.

10. Свропейський банк реконструкції та розвитку - банк 3 найбільшими обсягами залучених прямих іноземних інвестицій, а відтак, $\epsilon$ найбільшим інвестором у регіоні, створений у 1991 р.

11. Міжнародна організація кримінальної поліції (Інтерпол) спеціальний орган з центром у Відні, який бере безпосередню участь у боротьбі зі злочинністю [23].

Враховуючи вищезазначене, необхідно акцентувати, що у сучасному світі реалізуються різні схеми легалізації (відмивання) злочинних коштів. Єдиної класифікації таких схем як серед науковців, так і правоохоронних органів немає. Однак, на основі спільних характерних ознак їх можна згрупувати за такими критеріями:

а) за призначенням:

- 3 метою ухилення від сплати податків;

- 3 метою приховування злочинних операцій (легалізації засобів, одержаних від злочинів);

б) за типами систем розрахунків:

- готівкові;

- безготівкові (через платіжні доручення, пластикові картки, клірингові розрахунки тощо);

в) за організацією управління:

- 3 централізованим управлінням («конвертаційні центри») [24].

Для такої схеми характерна значна кількість злочинних операцій. Схема успішно функціонує за наявності централізованої ланки, яка організовує проведення операцій, що пов'язані 3 одержанням та передачею грошових коштів, здійснює контроль за роботою залежних фірм, веде облік тощо. Центральна ланка також виконує функцію захисту від правоохоронних органів. У випадку усунення або обмеження діяльності центральної ланки (наприклад, арешт керівників, банкрутство головної багатофіліальної фірми тощо) схема припиняє роботу.

Методи з централізованим управлінням характеризується ретельним забезпеченням функцій взаємодії між учасниками i, як правило, тим, що більшість фінансових ресурсів зосереджується саме в центральній 
ланці. Коли фінансові ресурси рівномірно розподілені по різних фірмах, централізоване управління $\epsilon$ неефективним. Воно не забезпечує необхідної надійності процесу відмивання коштів. Як наслідок, посилюється ризик конфліктів через невиконання своїх зобов'язань - 3 децентралізованим або розподіленим управлінням.

Для такої схеми характерний розподіл функцій управління між окремими фірмами, що поєднують лише разові операції або банк, через який здійснюються платіжні трансакції. У децентралізованій схемі легалізації (відмивання) злочинних коштів, порівняно з централізованою, мають місце проблеми захисту від правоохоронних органів.

г) за способом організації передачі інформації:

- 3 маршрутизацією інформації.

Взаємодія учасників схеми забезпечує визначення шляхів передачі злочинних коштів у різних формах за адресами їх призначення. Цей процес, як правило, виконується всіма учасниками системи.

- з селекцією інформації.

Взаємодія учасників схеми здійснюється через селекцію (відбір) адресованих їм різних форм злочинних коштів.

д) за технічним забезпеченням проведення фінансових розрахунків (методами доступу для проведення електронних трансакцій):

- 3 єдиними методами доступу, орієнтованими на електронні розрахунки (система «клієнт-банк», пластикові картки тощо);

- 3 використанням різних носіїв грошових коштів (готівка, пластикові картки, цінні папери тощо) [25].

Тип носія визначає властивості фінансової трансакції, яка здійснюється через організацію обміну певними зобов'язаннями. Найпростішим технічним засобом $є$ телефонна лінія. Ідеться про зниження вартості фінансової трансакції, по-перше, через невисоку вартість самого носія, по-друге, завдяки наявності на багатьох об' єктах резервних телефонних ліній, що можуть за необхідності використовуватися. До недоліків телефонних каналів здійснення злочинної фінансової трансакції з відмивання коштів належать недостатня захищеність від технічних перешкод, можливість несанкціонованого підключення (як правоохоронних органів, так і конкуруючих злочинних організацій), обмеження дальності й швидкості передачі даних наборами тих або тих компонентів електронної підтримки телефонної лінії.

Окрім того, проведений аналіз особливостей операційної діяльності 3 відмивання коштів дозволяє виділити типові схеми легалізації (відмивання) доходів, одержаних злочинним шляхом, які використовуються у сучасному світі. Нижче проаналізуємо кожну з них детальніше.

1. Легалізація (відмивання) коштів шляхом незаконної конвертації грошових коштів з використанням фіктивних підприємств.

2. Легалізація (відмивання) коштів шляхом здійснення спекулятивних операцій з цінними паперами. 
3. Легалізація (відмивання) коштів шляхом здійснення шахрайських операцій з землею та об' сктами нерухомості.

4. Легалізація (відмивання) коштів у результаті незаконного відшкодування з бюджету ПДВ та у процесі приватизації державного майна.

5. Легалізація (відмивання) коштів за участю банківських установ.

6. Легалізація (відмивання) коштів за участю небанківських фінансових установ.

7. Легалізація (відмивання) коштів з використанням САГП.

8. Легалізація (відмивання) коштів з використанням віртуальних валют.

9. Легалізація (відмивання) коштів з використанням Інтернетказино [26].

Проаналізовані схеми та методи легалізації (відмивання) доходів, одержаних злочинним шляхом, вказують на те, що відмивання коштів є злочином глобального характеру. Це пов'язано з тим, що суб'єкти легалізації (відмивання) коштів, виводячи свою діяльність на міжнародний рівень, переслідують такі цілі:

- уникнення країн/територій з чіткою нормативно-правовою базою та потужною правоохоронною системою;

- використання недоліків нормативної бази та роботи правоохоронних органів, характерних для низки юрисдикцій;

- використання прогалин, які існують при недостатньому рівні співпраці між правоохоронними органами різних країн;

- створення додаткових нашарувань транзакцій для того, щоб ускладнити відстеження руху злочинних доходів [27].

В останньому випадку часто використовуються країни, на території яких діють закони про таємницю проведення фінансових операцій. Такі юрисдикції називають «фінансовими притулками» або «офшорними зонами». Вони являють собою всю або частину території країни, де встановлюється і використовується пільговий режим функціонування компаній з офшорним статусом. Ідеться про ведення діяльності поза межами території реєстрації та проведення операції з майном чи коштами нерезидентів. Невеликі країни заохочують створення на своїй території офшорних компаній. Вони розвивають офшорний бізнес, який приносить цим країнам додаткові прибутки.

Вище проаналізовані схеми та методи складають далеко неповний перелік типових схем легалізації (відмивання) доходів, одержаних злочинним шляхом. 3 кожним роком вони стають більш складними та розгалуженими. Тому, необхідно запровадити порядок оприлюднення інформації про розкриті схеми легалізації (відмивання) коштів. Потрібно розробити методичні рекомендації щодо заходів, які будуть спрямовані, 3 одного боку, на попередження таких схем, а з іншого - на своєчасне їх 
виявлення. Доцільно також створити єдину електронну базу даних про суб'єктів таких схем, а також визначити типові параметри підозрілості осіб та операцій з легалізації (відмивання) доходів, одержаних злочинним шляхом.

В Україні система фінансового моніторингу перебуває у стадії формування та розвитку. Про переймання світового досвіду в сфері протидії легалізації злочинних доходів свідчить постійне вдосконалення законодавчої бази. Зокрема, 28 квітня 2020 р. Верховна Рада внесла зміни до Закону України «Про запобігання та протидію легалізації (відмиванню) доходів, одержаних злочинним шляхом, фінансуванню тероризму та фінансуванню розповсюдження зброї масового знищення» №361-IX. Він має суттєві доопрацювання порівняно 3 попереднім Законом, який втратив чинність [28].

До суттєвих удосконалень новоприйнятого Закону варто віднести більш деталізоване визначення дій, які можливо кваліфікувати як легалізацію (відмивання) доходів, одержаних злочинним шляхом, а також, удосконалено національне законодавство у сфері фінансового моніторингу. Також Законом розширено перелік суб'єктів первинного фінансового моніторингу, до яких додаються страхові (перестрахові) брокери, розповсюджувачі державних лотерей, адвокатські бюро та об’єднання, суб'єкти господарювання, що надають послуги 3 бухгалтерського обліку.

Організація ефективної системи запобігання та протидії легалізації доходів, одержаних злочинним шляхом, як у національному, так i міжнародному масштабах здатна істотно знизити мотивацію в одержанні таких доходів, виявляти і знищувати джерела їх походження, i, відповідно, скоротити кількість здійснюваних протиправних дій. У зв’язку з цим, запобігання та протидія легалізації доходів, одержаних злочинним шляхом, стали одними з найважливіших завдань як кожної окремо взятої країни, так і всього міжнародного співтовариства.

Водночас, існують сфери діяльності, у яких недоліки в організації фінансового моніторингу в Україні виявляються найбільш очевидно. Вони подані на рис. 2.

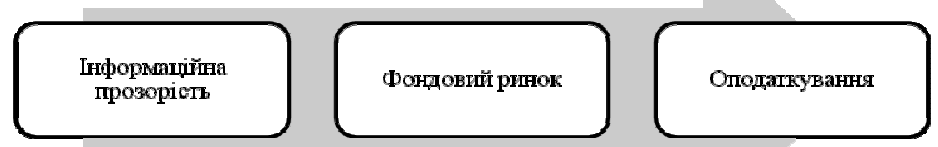

Рис. 2. Сфери, які виявляють найбільші недоліки в організації фінансового моніторингу в Україні

Джерело: сформовано автором на основі [29-32] . 
На території України відбуваються такі позитивні зміни:

- впроваджуються стандарти СС у боротьбі з відмиванням грошей та фінансуванням тероризму, спрямовані на подальшу імплементацію відповідного законодавства згідно зі стандартами СС;

- продовження взаємодії підрозділів фінансових розвідок України відповідно до стандартів групи Егмонта;

- збільшення спроможностей державних установ 3 визначення порядку та здійснення ефективного нагляду за фінансовими посередниками і представниками нефінансових професій;

- продовження обміну інформацією між підрозділами фінансових розвідок країн - членів СС та України про підозрілі фінансові операції, що можуть мати стосунок до відмивання грошей;

- продовження надання підтримки у навчанні суддів, працівників прокуратури, митників, співробітників правоохоронних органів та інших фахівців з фінансового моніторингу; продовження співробітництва в рамках роботи Комітету Moneyval Ради Свропи для забезпечення підтримки високих стандартів у процесі спільної оцінки всіх його членів та у типологічній роботі [33].

На підставі дослідження специфіки проведення фінансового моніторингу в світі можна визначити найбільш перспективні напрямки використання окремих особливостей світового досвіду в національній системі фінансового моніторингу в Україні (табл. 1).

Таблиця 1

\section{Напрямки використання світового досвіду в процесі реформування національної системи фінансового моніторингу в Україні}

\begin{tabular}{|c|l|}
\hline Країна & \multicolumn{1}{|c|}{ Особливість, що може бути використана в Україні } \\
\hline Канада & $\begin{array}{l}\text { перенесення на наступний бюджетний період невикористаних планових } \\
\text { бюджетних коштів }\end{array}$ \\
\hline США & $\begin{array}{l}\text { широка координація взаємодії органів, що протидіють легалізації доходів, } \\
\text { отриманих злочинним шляхом, та фінансування тероризму }\end{array}$ \\
\hline Італія & $\begin{array}{l}\text { підпорядкування фінансового моніторингу центральному банку, автоматизована } \\
\text { ризико-орієнтована система обробки інформації }\end{array}$ \\
\hline Австралія & $\begin{array}{l}\text { поєднання для реалізації фінансового моніторингу напрямків не лише протидії } \\
\text { легалізації доходів, отриманих злочинним шляхом, та фінансування тероризму, } \\
\text { ай ухилення від сплати податків }\end{array}$ \\
\hline Китай & $\begin{array}{l}\text { розмежування між окремими структурними підрозділами функцій управління та } \\
\text { реалізації фінансового моніторингу в рамках єдиного уповноваженого органу }\end{array}$ \\
\hline Фінляндія & відповідальність уповноваженого органу за процес попереднього розслідування \\
\hline Бельгія & $\begin{array}{l}\text { покладання на законодавчому рівні на уповноважений орган в сфері протидії } \\
\text { легалізації доходів, отриманих злочинним шляхом, та фінансування тероризму } \\
\text { функцій координації діяльності органів фінансового моніторингу }\end{array}$ \\
\hline $\begin{array}{c}\text { Велика } \\
\text { Британія }\end{array}$ & заборона передачі інформації про податкові правопорушення іншим державам \\
\hline
\end{tabular}

Джерело: сформовано автором на основі [34-36]. 


\section{Висновки:}

Дослідивши зарубіжну практику, передусім американський досвід протидії легалізації доходів незаконного походження, можна зробити висновок про можливість створення ефективної системи. Ефективність такої системи забезпечується не лише чинним законодавством, а й невідворотним виконанням його норм. Організаційні основи системи фінансового моніторингу в Україні загалом відповідають кращим світовим стандартам та рекомендаціям міжнародних організацій у цій сфері.

Існує низка переваг систем фінансового моніторингу в окремих країнах, які варто було б застосувати в Україні. Зокрема, зважаючи на досвід США та Канади, доцільно до фінансових злочинів в Україні віднести операції з предикатними до легалізації злочинами. Йдеться про комп'ютерне шахрайство, незаконні кредитні операції, підробку платіжних карток та інших платіжних документів, корупцію і зловживання службовим становищем, ухиляння від сплати податків. За прикладом США та Канади, в Україні доцільно посилити міжвідомчу координацію органів, які здійснюють нагляд у сфері протидії легалізації злочинних доходів. Необхідно створити закриту єдину систему для обміну інформацією щодо легалізації доходів між різними органами.

За прикладом Канади, Франції, США, доцільно забезпечити механізми збереження отриманої інформації у таємниці. Дотримання таємниці, зокрема, досягається за рахунок посилення адміністративної відповідальності уповноважених для роботи з секретною інформацією. Можливе застосування щодо окремих осіб таких заходів, як штрафні санкції, заборони обіймати керівні посади тощо.

За прикладом Канади, можливе розширення джерел отримання інформації в межах Державного фінансового моніторингу. Йдеться про інформацію щодо підозрілих операцій, отриманих 3 аналітичних доповідей, відкритих джерел масової інформації, яка ставатиме причиною більш глибоких досліджень спеціальних органів.

Необхідно посилити відповідальність суб'єктів первинного фінансового моніторингу за порушення законодавства у сфері протидії легалізації злочинних доходів. Зокрема так, як це відбувається у США, де комерційні банки сплачують по 10 тис. дол. за кожен день продовження відносин 3 клієнтами, які не подають необхідної інформації. Для порівняння: в Україні максимальний розмір штрафу для суб'єктів первинного фінансового моніторингу - юридичних осіб - становить близько 2,5 тис. дол. США за повторні порушення.

Доцільно посилити персональну відповідальність посадових осіб суб'єктів первинного фінансового моніторингу. За чинним законодавством, передбачено лише тимчасове відсторонення від посади до моменту усунення порушення. 


\section{Jimepamypa:}

1. Доля Л. М. Легалізація («відмивання») доходів, отриманих злочинним шляхом, як міжнародна проблема. Боротьба з організованою злочинністю і корупцією (теорія і практика). 2001. №4. С. 51-56.

2. Гулько Л. Г., Ільєва О. В. Організаційно-економічний механізм фінансового моніторингу в суб' єктів первинного фінансового моніторингу. Глобальні та національні проблеми економіки. 2015. №5. С. 863-866.

3. Гуржій С. Г., Копиленко О. Л, Янушевич Я. В. Боротьба 3 відмиванням коштів: правовий, організаційний та практичний аспекти : монографія. Київ : Парлам. вид-во, 2005. 216 с.

4. Money laundering through the securities markets. EAG Typology Report. URL : https://eurasiangroup.org/files/Typologii\%20EAG/WGTYP_ 2013_4_eng_copy0.pdf.

5. Василишин В. О., Леонов Б. Д. Міжнародне співробітництво у сфері боротьби з тероризмом. Державна політика у сфері протидіi тероризму: міжнародний досвід $і$ його актуальність для України : матеріали Інтернет-конференції. 2015. URL : http://www.ap.gp.gov.ua/ userfiles/file/Academia2016/sb_conf/konferens-25-06-2015.pdf.

6. Khalin O. Need for legislative Changts in the Mechanism of Ensuring the Effectiveness of the Investigation of Legalization of Proceeds from Crime. Віче. 2016. №5-6 (409-410). P. 44-46.

7. Варналій 3. С., Гончарук А. Я., Жаліло Я. А. Тіньова економіка: сутність, особливості та шляхи легалізації : навч. посібник. Київ : Нац. ін-т стратегічних досліджень, 2006. 575 с.

8. Коломієць I. В. Державний фінансовий моніторинг в Україні : сучасний стан і шляхи вдосконалення. Форум права. 2010. №11. С. $164-169$.

9. Корженівський Я. В. Методи легалізації (відмивання) доходів, одержаних злочинним шляхом. Науковий вісник Національного університету державної податкової служби Украӥни (економіка, право). 2011. №1(52). С. 289-295.

10. Egmont Group, 1995, The First International Meeting of Organizations Devoted to Anti-Money Laundering (Brussels). URL: http://www.golovan.com.ua/fileadmin/Blog/CASE_OF_GOLOVAN_v_U KRAINE.ukr.pdf.

11. Волковинська T. Співробітництво 3 FATF як фактор формування в Україні європейської моделі фінансової системи. URL : http://www.nbuv.gov.ua/portal/soc_gum/Un_msm/2007_12/Volkov.pdf.

12. Global Financial Integrity works to curtail illicit financial flows by producing groundbreaking research, promoting pragmatic policy solutions, and advising governments.URL: http://www.gfintegrity.org/.

13. Козак Ю. Г., Логвінова Н. С., Ковалевський В. В. Міжнародні фінанси : навчальний посібник. Видання 3-тє, перероб. та доп. Київ : Центр учбовової літератури, 2007. 640 с. 
14. Петрук О. М., Смагло О. В. Зарубіжний досвід організації фінансового моніторингу та перспективи його впровадження в Україні. WSPÓŁPRACA EUROPEJSKA NR. 2015. №2. C. 89-99.

15. Буткевич С. А. Досвід США щодо запобігання та протидії легалізації доходів, одержаних злочинним шляхом. Вчені записки Тавричного університету В.І. Вернадського. 2008. Т. 21 (60). №1. С. 68-74.

16. Куришко О. О. Аналіз світового досвіду у сфері протидії легалізації доходів, отриманих злочинним шляхом, у контексті можливості його використання в Україні. Фінансовий простір. 2013. №2 (10). С. 8-15.

17. Міжнародні стандарти 3 протидії відмиванню доходів та фінансуванню тероризму і розповсюдженню зброї масового знищення. Рекомендації FATF. URL : http://www.sdfm.gov.ua/content/file/ site_docs/ 2012/22.03.2012/1.pdf.

18. International Standards on Combating Money Laundering and the Financing of Terrorism \& Proliferation the FATF Recommendations (The FATF Recommendations). URL : http://000.fatfgafi.org/topics/ fatfrecommendations/documents/fatfrecommendations2012.html.

19. Іваницька О. М. Державне регулювання розвитку фінансової інфраструктури: монографія. Київ : НАДУ, 2005. 276 с.

20. Росоляк О. Фінансовий моніторинг: історія розвитку та досвід запровадження в Україні. Фінансове право. 2005. №11. С. 30-32.

21. Васенко В. К., Челядіна О. С. Боротьба 3 легалізацією (відмиванням) незаконно отриманих грошей. Безпека і право. 2012. URL : http://pb.univd.edu.ua.

22. Коваль Я. С. Державний інструментарій ідентифікації ризиків, як елемент попередження негативного впливу на економічний стан банківської системи. Вчені записки Університету «КРОК». 2019. №1(53). C. 65-74. DOI: https://doi.org/10.31732/2663-2209-2019-53-65-74.

23. Омельченко І. Легалізація брудних грошей. Юридичний журнал. 2010. №3. URL : http://www.justinian.com.ua/article.php?id=3456.

24. Сгоричева С. Б. Стадії та інструменти легалізації доходів, одержаних злочинним шляхом. Організація фінансового моніторингу в банках : навчальний посібник. Київ : Центр учбової літератури, 2014. 292 c. URL : http://pidruchniki.com/68436/bankivska_sprava/stadiyi_ instrumenti_legalizatsiyi_dohodiv_oderzhanih_zlochinnim_shlyahom.

25. Росоляк О. Фінансовий моніторинг: історія розвитку та досвід запровадження в Україні. Фінансове право. 2005. №11. С. 30-32.

26. Соловій Я. І., Дудка В. В., Дудка А. В. Легалізація (відмивання) доходів, одержаних злочинним шляхом : монографія. Івано-Франківськ : Наддвірнянська друкарня, 2008. 231 с.

27. Савченко О. Становлення та розвиток системи фінансового моніторингу в банках України. URL : https://kneu.edu.ua/userfiles/ Credit_Economics_Department/KMBD/konkurs/Konkyrs2016/Savchenko_ 
Oksana_Stanovlennya_ta_rozvitok_sistemi_fD196nansovogo_monD196to ringu_v_bankah_UkraD197ni_.pdf.

28. Про запобігання та протидію легалізації (відмиванню) доходів, одержаних злочинним шляхом, фінансуванню тероризму та фінансуванню розповсюдження зброї масового знищення: Закон України від 28.04.2020 p. №361-IX. URL : https://zakon.rada.gov.ua/laws/show/361-20\#Text.

29. Коваль Я. С., Мігус І. П., Андрієнко В. М. Міжнародний досвід формування державної політики у сфері забезпечення фінансової безпеки як складової національної безпеки. Демократичне врядування. Львів, 2017. Вип. 20. URL : http://www.lvivacademy.com/vidavnitstvo_1/ visnyk20/index.html.

30. Thony J. F. Processing Financial Information in Money Laundering Matters, The Financial Intelligence Units. European Journal of crime, Criminal Law and Criminal Justice. 1996. p. 3.

31. Розенфельд Н. А. Заходи підвищення ефективності кримінальноправового забезпечення протидії фінансуванню тероризму та легалізації доходів, здобутих злочинним шляхом. Актуальні питання вдосконалення начіонального законодавства України у сфері запобігання та протидіі легалізації доходів, одержаних злочинним шляхом, $i$ фінансування тероризму : збірник матеріалів конференції за підтримки Програми Європейського Союзу ТАСІС Проекту з питань боротьби з відмиванням коштів та фінансуванням тероризму в Україні (MOLI-UA-2), 18 грудня 2008 р., м. Київ. Київ, 2008. С. 52-70.

32. Шкурко В. I. Історія становлення та розвитку правового регулювання співробітництва держав-членів СС з протидії легалізації доходів, отриманих злочинним шляхом. Міжнародне право. 2019. №145. C. 256-267. DOI: 10.21564/2414-990x.145.163662.

33. Холдер Э. Механизмы и процедуры возвращения активов в США : практическое руководство для международного сотрудничества. Вашингтон : Государственный департамент США, Министерство юстиции США, отдел уголовных дел, отделение конфискации активов и борьбы с легализацией незаконных доходов, A/GIS/GPS, 2012. 21 с.

34. Olson M. and Zinnes C. The Shadow Economy: Friend or Foe? World Development. 2002. 56 p.

35. Бисага К. В. Нормативно-правове регулювання в Свропейському Союзі протидії відмиванню доходів, одержаних злочинним шляхом, фінансуванню тероризму та розповсюдженню зброї масового знищення (наднаціональний рівень). Вісник НАДУ при Президентові України. Серія «Державне управління». 2016. №3. С. 35-42.

36. Москаленко Н. В. Фінансовий моніторинг як інструмент економічної безпеки. Науковий вісник Львівського державного університету внутрішніх справ. 2009. №1. С. 1-7. 